\title{
Expanding the Frontiers of Labour History: Kjartan Fløgstad's Synthesis of Local, Global, and Environmental History*
}

\author{
FRANK MEYER \\ Faculty of Social Science, Oslo University College \\ E-mail: Frank.Meyer@sam.hio.no
}

The company that ran the ironworks on the other side of the river, and that had not acted that badly, was the same firm that was responsible for the greatest industrial catastrophe in history, and the gravest work accident that had ever occurred in the USA. It was responsible for one of the worst epidemics of lung disease here in our own country. In Norway, no one had ever heard of Hawk's Nest. In the USA, no one had ever heard of the Electric Furnace Products Company, Limited. In Bhopal, India, no one had ever heard of Hawk's Nest or Electric Furnace. Was this situation tolerable? Was it? Kristoffer Jakobsen, Franz Oskar Johansen and the other union representatives at EFP were not acquainted with union representatives in West Virginia or in Bhopal. The reverse was also true to the extent that these enterprises were at all unionized. However, all of these employees worked for the same firm and suffered from the same problems. They were unaware of one another. In the last analysis, neither union representatives nor historian colleagues of mine provided any information. Two writers provided the information. They were two women who were outsiders to these events, the authors Muriel Rukeyser and Arundhati Roy.

Kjartan Fløgstad, Grand Manila (Oslo, 2006) pp. $365 \mathrm{f}$.

\footnotetext{
* I am indebted to Larry Young who translated this text from Norwegian to English. This article is part of a project entitled: "Looking at the Feet of an Elephant: Working and Living Conditions in Company Towns, Interconnected by a Transnational Commodity Chain". The aim of the project is to describe and analyse the global process of modernization - the transformation from traditional to industrial to post-industrial society - by studying two local communities that are linked together by an international company. The Norwegian Museum of Industrial Labour in Rjukan has generously supported this project by providing funds from The Foundation for the Study of Culture in Industrial Worker Communities. In addition, I have received a stipend from the EU's Leonardo da Vinci Programme to help me improve my language skills in Portuguese. I am very grateful for this support. Finally, warm thanks are extended to Knut Kjedstadli, Kristen Nordhaug, Ola Alsvik, Marcel van der Linden, Aad Blok, and Sindre Bangstad for their helpful comments.
} 
In this essay, I would like to draw attention to the non-fictional writings of Kjartan Fløgstad - and particularly to the commissioned business history of the metallurgic industry in his hometown, Sauda, in southern Norway. Arbeidets lys: Tungindustrien i Sauda gjennom 75 ar (which might be translated into English as The Work of Illuminance: Heavy Industry in Sauda over 75 Years) is a work that I consider to be extremely important because of the ways in which it has expanded the frontiers of labour history. ${ }^{\mathrm{I}}$ What distinguishes Fløgstad's work is that it compares empirically production and labour control at the different nodes of a transnational commodity chain. According to Marcel van der Linden this has not been attempted in any research on transnational labour history. ${ }^{2}$

For non-Scandinavians, it may be necessary to introduce Fløgstad briefly. During the past thirty years, Fløgstad (b. 1944) has won the most prestigious Norwegian and Nordic literary awards with his fictional writing. In addition, he has written non-fictional works in the fields of labour and environmental history. The works of the Booker prize-winning author and political essayist, Arundhati Roy, and the works of the American poet Muriel Rukeyser have been important influences in this endeavour.

What makes Fløgstad's writing particularly relevant for the expansion of the frontiers of labour history is the fact that his writing - in addition to dealing with traditional issues of labour history - oversteps the borders of three well-established genres in historical and sociological research, and

I. Kjartan Fløgstad, Arbeidets lys: Tungindustrien i Sauda gjennom 75 år (Oslo, 1990). All intext references are to this work. As far as this author can determine, the book's thematic, methodological, and narrative value has only been discussed by Ingar Kaldal, in a short and incomplete review of the book in the Norwegian journal, Heimen. As I expected, there was no reference to the book in one of the most recent and prestigious texts within business history on the history of the Norwegian multinational, Norsk Hydros historie. Ingar Kaldal's review is found in Heimen, 4 (199I), pp. 240-24I, in the category entitled Bedriftshistorie [Business history]. See Norsk Hydros historie 1905-2005, 3 vols (Oslo 2005). Cf. R.P. Amdam, D. Gjestland, and A. Hompland, Ardal. Verket og bygda 1947-1997 (Oslo 1997).

2. Marcel van der Linden, "Globalizing Labour Historiography: The IISH Approach", at http://www.iisg.nl/publications/globlab.pdf, pp. 9-10 (last consulted I2 November 2008). Social and historical research on interconnected cities has not in any substantial sense focused on relatively small company towns in different parts of the world, but rather on what sociologist Saskia Sassen has called "global cities" such as, for instance, New York, London, Tokyo, Hong Kong, São Paulo, Mexico City, and Mumbai. These metropolises can be regarded as nodes first and foremost in global networks of financial transactions, communication and innovation; Saskia Sassen, Cities in A World Economy (2nd edn, Thousand Oaks, CA, 2000), pp. $4^{-5}$. But seen in a wider context, these cities cannot be regarded as typical for the development of cities on the globe. There are substantial differences in the roles different cities play. One type of city, such as Timbuktu, is based on the production of and trade with relatively basic handicrafts, as it has done for centuries. Other types of city have more and more become the home of the production of IT products such as PCs, telephones, and TVs. A third type of formerly prosperous city has encountered a substantial decline since the I970s, such as industrial cities in mid- and northern England or in the American midwest. 
defines new standards for a synthesis that also combines elements of local, global, and environmental history writing. The three well-established genres are business history, local history, and research on commodity chains.

\section{BUSINESS HISTORY, LOCAL HISTORY AND RESEARCH ON COMMODITY CHAINS}

Business history is a category within historical research that is exclusively interested in the fate and fortunes of a specific firm. It is this microhistorical point of view that distinguishes business history from economic history, which has a macro- and, to some extent, quantitative historical perspective. Together with the specific firm which is in focus as an organization, the owners and managers of the firm are accorded the most attention by historians, because owners and managers decide upon which products to produce and on the means of doing so. In addition, other individual agents may be given a key role in these historical narratives. Politicians, upper-echelon public servants, functionaries, and other business leaders play a role in the unfolding story. As a consequence, the actions of an individual can easily hog the limelight in a business history. ${ }^{3}$ This is a clear limitation that Flogstad manages to transcend.

Beyond relating the history of a specific firm, Fløgstad has the ambition to write the history of the small local community in Sauda, "that grew up in the surrounding smoke and in the shadows that were cast by the brown furnaces in the massive ironworks" (p. 8). This ambition is far removed from the business historian's task and usual practice, and it is here that Arbeidets lys is in contact with another tradition in Norwegian historiography, local history. ${ }^{4}$

Local history can be defined as "all studies of areas below the national level". This includes studies of local communities for their own sake and studies that are of more general interest and which describe developments which take place at the local community level. The limitation that I want to point out here in this form of historical research is a form of tunnel vision operating at the local level. At its worst, local histories can be written in almost complete isolation from their surroundings, as if the story took place on a desert island in the middle of the ocean, where the natives lived in

3. E. Lange and H.W. Nordvik, "Economic History", in W.H. Hubbard et al. (eds), Making a Historical Culture: Historiography in Norway (Oslo 1995), pp. 26I-288, 268 and 272.

4. The web page http://www.lokalhistorie.no provides a general overview of local history written in Norway. Local history is a category that is given special importance within the field of Norwegian historiography.

5. G. Thorvaldsen, "Om grenser og områder i lokalhistorisk forskning” [On limits and areas within local historical research], in K. Kjedstadli, J.E. Myhre, and T. Pryser (eds), Valg og vitenskap: Festskrift til Sivert Langholm (Oslo, I997), pp. I88-2 I I; H. Winge, "Local History", in Hubbard, Making a Historical Culture, pp. 240-260. 
a paradise of innocence. Of course, this is a purely cultivated version of local history and, as a rule, the surrounding environment is included in the narrative, whether this means providing demographic information, industrial developments, or policies that are determined at a higher level. Even so, local history narratives are like earthquakes that are weaker and weaker the farther they move from the epicentre. For those who begin by claiming that we live in a day and age when more and more of the residents of the globe are linked together in a global network, and that they are drawn into mutually dependent relationships, facts that support this view will not, as a rule, be sufficiently reflected in a written local history.

The third methodological influence on Fløgstad's work can be seen in sociological research on global commodity chains. The term commodity chain was introduced by Terence Hopkins and Immanuel Wallerstein, and means "a network of labour and production processes whose end result is a finished commodity". 6 A global commodity chain "consists of sets of interorganizational networks clustered around one commodity within the world economy. These networks are situationally specific, socially constructed, and locally integrated, underscoring the social embeddedness of economic organization", and "the greatest virtue of a commodity chain is its emphasis on process". 8

Each successive node within a commodity chain involves the acquisition and/or organization of inputs (e.g., raw materials, or semi-finished products), labour power (and its provisioning), transportation, distribution (via markeds or transfers), and consumption. The analysis of a commodity chain shows how production, distribution, and consumption are shaped by the social relations (including organizations) that characterize the sequential stages of input acquisition, manufacturing, distribution, marketing and consumption. ${ }^{9}$

However, on the down side, these studies often lack historical depth and micro-social context.

The main methodological extension of the frontiers of labour history from Fløgstad's work can be seen in the empirical comparison of production and labour control at the different nodes of a transnational

6. Terence K. Hopkins and Immanuel Wallerstein, "Commodity Chains in the World Economy Prior to I 800", International Review of Social History, Io (1986), pp. I 57-170, I 59. Marcel van der Linden has made us aware of the French filière approach in the I960s that anticipated key elements of the commodity chain research; see Van der Linden, "Globalizing Labour Historiography”, p. 9.

7. Gary Gereffi, Miguel Korzeniewics, and Roberto P. Korzeniewics, "Introduction: Global Commodity Chains”, in Gary Gereffi and Miguel Korzeniewics (eds), Commodity Chains and Global Capitalism (Westport, CT, I994), pp. I-I4, I.

8. Terence K. Hopkins and Immanuel Wallerstein, "Conclusions about Commodity Chains", in Gereffi and Korzeniewicz, Commodity Chains, pp. 48-50, 50.

9. Gereffi, Korzeniewics and Korzeniewics, "Introduction", in ibid., p. 2. 


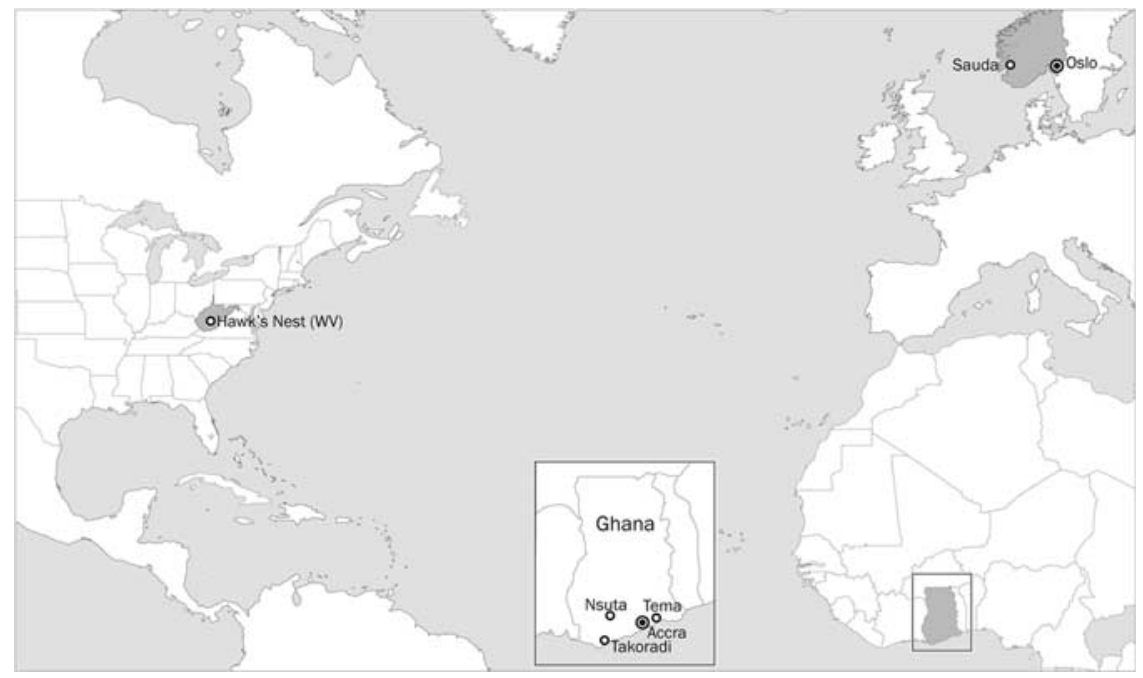

Figure. I. Global locations of the Union Carbide manganese mining and production sites.

commodity chain. According to Van der Linden, this has not been attempted in research on transnational labour history. ${ }^{10}$

\section{THE CAPITALIST WORLD SYSTEM}

What clearly distinguishes Fløgstad's history from works of business history and local history is the emphasis he places upon a macro-sociological and macro-economic approach, in addition to the fact that his analysis focuses upon the micro-level, i.e. the firm and the local community under study. This last feature distinguishes his approach from the research on global commodity chains elsewhere.

From the very first page, Fløgstad points the attention of his readers to the capitalist system of which Sauda was a part. Sauda was located in the middle of a global triangle that stretches from the east Coast of the USA to the African Gold Coast, and from there to the Norwegian Rain Coast. The Sauda electric furnace plant was founded on American capital, African ore, and Norwegian hydro-electric power. Sauda was certainly not the only community that was incorporated into this triangle; many other company towns and regions were included.

Americans built and had control over the system that linked the parts of this global triangle. Electric Furnace Products Ltd. (EFP), which was the firm's name in English, was officially a Canadian-owned corporation 
in Norway. The Canadian firm was a subdivision of Union Carbide of New York, an American large-scale industrial corporation.

This arrangement, which solely was constructed in honour of the tax authorities on both sides of the Atlantic, was spoken about by EFP's representatives whenever the occasion to do so arose. This included zealous, and at times, comic displays to avoid providing any information about the firm or about the way in which it was run. (p. 21)

The system had its own mad logic, a cynical and anti-human logic, even though it was a human creation. The system was built upon unequal power relationships between capital and labour, and those who wielded American capital ran the operation without regard to anything beyond the firm's profits. Politicians at the local and national level usually had very little or no room to manoeuvre. National states were transformed to manganese republics or monarchies. The space for political decision-making in Sauda was reorganized into an "oriental bazaar" (p. 175). More often than not, bare need forced Norwegian policies to follow American requirements. The residents of Sauda - who stood pars pro toto for the industrial community - were "imprisoned in their self-produced conflict between politics and economics" (p. 68). The political powerlessness was on display when, for example, the Norwegian Parliament provided licenses to develop hydro-electric power at Sauda, or by the boycott of the South African apartheid regime. Malm from South Africa was smelted in Sauda. It would have been practically possible to replace the South African malm with malm from Gabon, Brazil, or Australia, but that would have created additional and extensive technical processes and new investments.

By imposing a one-sided boycott, Sauda would have priced itself out of the market. [...] Like every other dilemma there was no easy solution. It was easy to become a cynical realist. On the other hand, it wasn't difficult to become an abstract humanist and to privately be a huge consumer while asking the people of Sauda to wholeheartedly support policies that would have led to their own extinction. (p. 67)

\section{COMPARING NODES OF A GLOBAL COMMODITY CHAIN}

In my opinion, a transcendatory analytic and narrative move was made by Fløgstad in Arbeidets lys in focusing the awareness of his readers upon another local community - or perhaps it is more appropriate to say another region - in the global world system, i.e. Nsuta in Ghana. In my view, he transcends the framework that is found in the models for his work, namely Arundhati Roy's essay on the environmentally catastrophic Narmada dam that was built in India and Muriel Rukeyser's description of the working conditions in the mines owned by Union Carbide in Hawk's Nest, which led to the suffering and death of many workers due to asbestosis. In contradistinction to Roy or to Rukeyser, Flogstad does 
not limit his analysis to one local community, but expands his analysis by drawing-in several other local communities where the same multinational corporation has undertakings. One might say that he attempts to look at the different feet of an elephant.

Nsuta and Sauda are two aspects of the same thing, according to Fløgstad. "Both have been rapidly created from undeveloped hinterlands and have been brought into the economies of industrial nations. As communities, they had many common characteristics, which, of course, were modified by local differences. Nsuta was even more of a company town than Sauda would ever be" (pp. 55f.). The similarities of the local communities were demonstrated when Union Carbide built the heavy industry in Sauda almost simultaneously with the infrastructure in the Gold Coast of West Africa in order to exploit the manganese mined from Nsuta. The ore was transported by rail to the coastal city of Takoradi, where a deep-water harbour was built from 1923 to 1928 . "In so doing, an effective transportational system between the mines of Nsuta and the factories of Sauda was put into operation", which lasted for forty years, solely interrupted by the years of World War II. The technical apparatus in Takoradi was almost identical to the apparatus used "extending the transportation system from the other side of the ocean, 4,3 Is nautical miles away, to the docks of the wharf in Sauda, where the brown ore from the Gold Coast was placed onshore and stored under the cable railway until the late 6os" (pp. 53 f.). Yes, even the jungle "deep into the interior of Ghana had the same colour as the furnace roofs in Sauda" (p. 54).

The American-controlled industrialization mercilessly remodelled these two towns, and every other town that was drawn into the firm's worldwide undertakings. It was often the case that the demise of one place led to the development of another. Takoradi replaced another harbour, Sekondí, where the harbour conditions were too poor to justify further investments. But these days, the port of Takoradi is empty.

A modern harbour was built in Tema, directly east of Accra, and it has taken over most of the traffic. Takoradi is too small and the equipment is out of date. The formerly busy harbour town seems to be half empty and sleepy. A few kilometres away, you find the oldest harbour on the coast, Sekondí, which is a threatening reminder of the next stage of decay. The harbour district is disfigured by poverty and misery. Several buildings are in a state of ruin. [...] In the middle of the town you discover a huge, open garbage dump, where emaciated cows wander amidst the impoverished inhabitants and the housing ruins. [...] Sekondí is now separated from the international economy. (p. 53)

Since the history of heavy industry in Sauda is written as a history about industrial capitalism as a system, the specific circumstances that led to its decline are not what is of interest, even though they had more or less tragic consequences for the people in towns like Sauda, Sekondí, or 
Sheffield. On the contrary, a global and cyclical understanding of the events that are described is what characterizes Arbeidets lys.

A major tendency in modern capitalism connects selected areas in the third world to the economies of industrial societies and in so doing these areas are disconnected from their own surrounding undeveloped hinterlands. At present, this occurs in export-producing parts of the Caribbean, in the coastal provinces of China, and in the northern areas of Mexico. It occurs in some parts of Africa and Latin America, too, particularly those areas that have mining industries and industries to extract oil. Global restructuring binds together the economic resources and technological advances in different countries at the world level and disconnects social groups, hinterlands, cities and towns and sometimes entire nations that are not included in the new and dynamic technologically based economic system. Areas and people that were formerly connected to that system become disconnected, like the harbour workers in Sekondí when the harbour was closed, and the English steelworkers who lost their jobs when Sheffield was transformed into an industrial museum. (p. 58)

We can probably use the same analysis to include Sauda. What was once advantageous for Sauda, and for other towns with heavy industry, is now disadvantageous because new conditions for production have been introduced. While industries were, and continue to be closed down in western countries, they are being built-up again in other countries. Stainless steel knives that were formerly produced in Sheffield are now being imported from China, Taiwan, and Korea. The brand name is then stamped on the product in Sheffield. ${ }^{\text {II }}$

From the head of a fjord in Indre Ryfylke, where the combination of malm produced in an African colony, cheap Norwegian hydroelectric power and Canadian tax laws made it a good place to be, the money has been moved to new hunting grounds. There is no reason to doubt our words that a far-removed post office in the heart of Brazil's rainforest is being used to send Electric Furnace Products Company envelops anonymously and without a return address to Cragmar and Hamilton in Bermuda. (p. 58)

Since it is the world system that Fløgstad places Sauda within, few references are made to "the good old days" before carbide's golden age ends. This is made clear when Fløgstad points out that the production system was converted to make weapons for the arms industry. Wars, great

I I. One may characterize the dichotomy of either being connected to or being disconnected from the global economic system as a reaction to a crisis, as Knut Kjedstadli has done in his article entitled "Lokal internasjonalisme", in Amdam, Gjestland, and Hompland, Ardal, pp. 38-55. International owners can sometimes be pressured to react to changes in the world economy by changing their production processes rather than closing down an industrial plant. Alternatives include nationalizing those industrial plants that owners plan to close down or establishing new enterprises on the premises. 
international conflicts and times of relative peace are what create movements, rises and declines, in the world's economic system. EFP was established during World War I, and its business was booming throughout World War II and the Korean War.

If your perspective is sufficiently narrow, rumours about discord and acts of war were good news for the local community of Sauda. The wheels at the power station moved more quickly and new production was initiated. More people were employed and the local authorities received increased revenues and were able to plan and provide for new public services. The metallurgical industry is, as the saying goes, one that is very sensitive to changes in the business cycle. [...] When bombs and grenades explode in enemy camps, destruction, death and misery follows in its wake. But we all know that the war economy also leads to general increases in production, particularly in heavy industries, and to dramatic increases in the need for a long list of products, amongst others, and not the least of which are products that are based upon carbides. (p. 4I)

What is further worthy of note regarding Fløgstad's global and clearly neo-Marxist description of local history is that it never seems to be reducible to a simple formula. This is quite clear, for example, in the way in which he provides a differentiated explanation of causes that led to Sauda being disconnected from the world economy in 1981. Fløgstad points to five partial causes. First of all, the firm expanded and diversified its production, but the iron alloy industry began to shrink and eventually it was of very little importance. Second, the worldwide supply of iron alloys was far greater than demand. Third, the tax authorities in Norway and Canada made changes in their rules and regulations that were disadvantageous to Union Carbide. Fourth, management changed its strategy and allowed for an increase in the democratic representation of employees in the boardroom. All of these changes "coalesced and the result was that Sauda Smelteverk A/S was no longer an uncontrolled money-making machine" (pp. I99f.), as it formerly had been. In addition, the Board and company managers were of the opinion that technological innovations would eventually make manganese smelting unnecessary.

As I have already mentioned, in my opinion this bifocal scrutiny of two local communities and their interactions within the global economy, and the global system-oriented approach to writing business history has, in a very positive way destroyed the boundaries between business history and local history as these were formerly defined. I will now address a second matter where I also believe that Arbeidets lys has proved to be highly innovative.

\section{THE METABOLISM BETWEEN MAN AND NATURE}

The relentless march of capitalist industrialism has had profound implications for what Karl Marx referred to as the metabolism between man 
and nature. Substantial changes have occurred at three different levels: man's remodelling of the natural environment; the environmental consequences of that remodelling for man's physical living conditions; and the psychological consequences that have followed, the mental assimilation that is required for adaptations in man's physical human nature.

The fate of human beings is to always be dependent upon the metabolism with nature. This metabolism occurs at different levels, depending upon technological and industrial developments. ${ }^{\mathrm{I} 2}$ This is another leitmotif within Arbeidets lys, and I believe this choice of theme explodes the boundaries for other business and local histories. The metabolism between man and nature is ordinarily described by a discussion of its various stages. The following description is an attempt to provide a simplified version.

\section{Man's remodelling of the natural environment}

A first stage in the taming of nature, one that was very far from paradise on earth, existed in the period before heavy industry was established in Sauda. Agriculture in Sauda and in Ryfylke was cultivated in the traditional way, and the first industrial workers were farm boys who "were raised on small farms in the district. [...] where the methods used hadn't changed very much in the past hundred years" (p. 76). At the beginning of the twentieth century, Ryfylke was impoverished. Humans were trapped in primitive household economies and the only escape from their hold was to emigrate to America.

Even the smallest tufts of grass growing in wild mountain terrains and in the steepest heights were cut down by farmers using scythes, dried on the ground, roasted and rolled home on rods to be used as winter feed for the livestock. In I9I4 agriculture $[\ldots]$ continued to be an occupation that was carried out in traditional fashion, without any mentionable connection to a money economy. (p. 44)

When Sauda became connected to the worldwide industrial economic system, great changes were made in the metabolism between its human residents and the natural surroundings. The entire natural environment surrounding Sauda was changed.

In the mountainsides and in the valleys separating the mountain peaks and the lowest power station in Sønnåhamn in the Sauda fjord, Sauda residents had, throughout the years, built up an ingenious system of dams, storehouses, drainage tunnels, transport tunnels, power stations, crossroads, river crossings, and junctions for connecting electrical wires. [...] This was a landscape that had lost all of its natural innocence. (p. 49) 


\section{The environmental consequences of that remodelling for man's physical living conditions}

The industry that was built up led to a completely new relationship between man and nature. The standard of living in the industrial town increased rapidly, and Fløgstad rejects the vulgar Marxist interpretation of the newly created proletariat.

It would be fallacious to identify them as proletarian, in the sense that they were impoverished. Objectively, the industry provided its workers with a higher standard of living. Subjectively, the workers experienced being wage-slaves under capitalism as a dramatic liberation from the bonds of slavery to nature in a subsistence economy based upon agriculture. (p. 8)

But far from being a utopian story about human liberation from the constraints of nature, industrialism consisted of a new kind of bondage to nature, a new metabolism between man and nature. The changes do not solely encompass changes in the environment, but include changes in the human body itself. The environment, or the external aspects of nature were systematically exploited, but human nature, or the internal aspect of nature was also devoured by industrialism. Human beings could feel the transition to industrialism with their bodies. The way in which the melting furnace was operated for the first seventeen years, including open ovens, resulted in a thick, brown smoke which arose from the ovens and settled upon the local community and the adjacent fjord. In step with the release of toxic waste in the form of manganese smoke was an increase in the number of people suffering from lung diseases in the community. The most dramatic consequence was death by what came to be known as Sauda-pneumonia. According to Fløgstad, this was probably the highest price the Sauda residents had to pay for the establishment of the industry in their community.

The exploitation of the surrounding environment and the damage to human nature was brutal, not only in Sauda, but also in Nsuta, and everywhere else that industrialism established itself. The owners of these industries in western nations had to yield to the demands made by the environmental movement, but this was not the case in the south. "The unfettered race to maximize profits has had the most tragic consequences in the Third World. As a consequence of the toxic waste catastrophe at Union Carbide chemical factories in Bhopal, India, 86,000 people became invalids and 3,500 people lost their lives” (p. I36). In Sauda, on the other hand, air pollution was reduced. The factory replaced the open melting ovens with closed ovens and Sauda-pneumonia disappeared.

After 50 years of being covered in smoke, residents of Sauda, once again, could witness the sun shining in the sky. It was still red and round! Satisfied, we stood on the export wharf and saw the sun reflected in the surrounding waters. 
They were thick and brown from the waste materials that spilled out of the ovens and directly into the sea. The pollution problem had been solved. Or in any case, it had, at least, been moved, for the time being. (p. 84)

One can almost choke, laughing. The metabolism between man and nature did not disappear. It was only transformed to a new level.

\section{Industrialism colonized man's inner nature}

Psychological adaptation is needed to be able to cope with the changes that are manifested in the surroundings and in one's own inner nature. Again, nature is not only found in man's surroundings. The human body and the human mind are also products of nature. This being the case, man's body and mind (inner nature) participate in a metabolism with man's surroundings (outer nature). One example of this that is provided in Arbeidets lys concerns the industrial practice of working in shifts. The natural human rhythm between periods of rest and periods of activity is broken down and made subservient to maximizing profits under capitalism.

The irregular hours of work create very specific social problems. In industrial towns dominated by a particular industry, these problems affect the entire community. When lots of people work evening and night shifts, large numbers are excluded from the community's organized leisure-time activities. They are unable to attend public meetings and they can't watch the popular television programmes. [...] Those who work these shifts for long periods of time don't get enough sleep and they don't have the energy to participate in voluntary organizations. When they aren't working, it would be nice to be able to have a beer with their friends in a pleasant locale [...] or take a walk together [...]. For those who work on evening or night shifts, this will often mean that your leisure-time pursuits are messy and haphazard. It is easy for weak souls to get into bad habits and to misuse alcohol and other drugs. (p. 73)

Beyond the psychosomatic problems, there are also special forms of awareness and understanding that are connected to the different stages in the metabolism with nature. Human beings are in themselves a part of nature and their subservience to nature is not always clearly recognized. This makes it possible for humans to find new ways to be aware of nature. These understandings spring forth dialectically as man finds new ways to utilize and control nature. The understandings do not occur at the same time that new forms of power over nature are established. On the contrary, new understandings are acknowledged later on, and they appear to be a delayed cultural response to the consequences of man's remodelling efforts. This is the way that Flogstad criticizes the initial and wholehearted rejection by scientists of the idea that the smoke generated by the melting furnaces had anything at all to do with the increased incidence of lung disease. "Time heals all sores, (but) time also 
injures some healers" (p. 135). The fact that the ways in which man understands the world is in sync with the new metabolism established between man and nature affects everyone, including workers and the labour movement.

The proletariat has nothing to lose but its chains, chains that are forged from steel. And there is an entire world to win. A less optimistic developmental slogan would claim that the chains are connected to something very deeply embedded in human nature. [...]. The chains within us... and the chains placed upon us by our surroundings $[\ldots]$. The symbolic language used by the socialist labour movement is connected to those very same chains and to the steel used to forge them. It may be so, the environmental crisis seems to be trying to tell us, it may be so, the breakdown of "the scientifically realized state of socialism" seems to be saying $[\ldots]$ that heavy industry and the forms of thought generated by industrialism are built into those chains, not only the exploitation of the industrial workers. Liberation from the steel used to forge the chains, and from the polluting heavy industry that produces them, contributes to breaking the chains of solidarity as well as the chains used to enslave the working class. (p. 2I2)

\section{CRITIQUE AND CONCLUSION}

Even though I consider Arbeidets lys to be a work that has shattered former boundaries, the book is not without gaps or unsolved problems. There are four areas that I would like to see examined in greater depth in scholarly research to come.

(I) As Fløgstad himself states, the book is primarily about men. The reason he gives is that women did not participate seriously in production at EFP before 1970. However, that argument in itself invites a wider criticism. Besides women, there are other groups that fall outside the perimeters of his presentation. This includes, more specifically, all those residents who were not wage-earners connected to the industrial production in Sauda. This includes women (who it might be added are not given much attention even after I970), children, youths, pensioners, the disabled, and others who are only mentioned in passing or not at all. Seen in this way, the group of people that Fløgstad studies and writes about as "those of us that grew up in the surrounding smoke and in the shadows that were cast by the brown furnaces" (p. 8) is indeed quite reduced. Where are the children, families, pensioners, the disabled, and others who did not participate in the industrial production, but who, just like the industrial workers, lived and died under a blanket of smoke? One may ask why Fløgstad, relying upon his own memory and without needing to employ a great deal of effort did not weave in more experiences of their lives, to express their power and 
powerlessness and their social functions within the local community network. ${ }^{13}$

(2) Fløgstad describes and analyses the metabolism between humans and nature in the industrial age in a path-breaking manner. A reservation can be made in his analysis of that metabolism in the post-industrial period. There we find a lot of hints but less in the way of analysis. For example, in a longer interpretation on soccer and post-industrialism, he writes:

In the industrialized countries, social relationships are no longer confined to naked class relations. Communication replaces work as the force that creates social structures in society. Cultural capital becomes as important as economic capital. However, the contradictions in society always continue to reflect class relationships. In the developing countries, the exploitation of humans and nature is apparent in the most blatant way. Today, the third world is third-rate. We witness the most shocking consequences of the failure of the labour movement to achieve parity with those who wield capital. (p. 58)

The challenge is to describe the conditions that exist after the transformation from industrial culture to the culture industry. ${ }^{\mathrm{I}}$

(3) The criticism has been raised that one never becomes acquainted with the people Fløgstad describes from the inside. ${ }^{15}$ This is a criticism that is also true for Arbeidets lys. In my opinion, it would be desirable to have a tighter grasp of certain cultural phenomena, if one wanted to expand historical studies in the direction that Fløgstad has taken. It would be very helpful to know more about the mentalities of the people who lived in pre-industrial, industrial, and post-industrial times, and this would include individuals and groups who were directly connected and indirectly connected to industrial production.

(4) As I have already pointed out, in my opinion, the perspective that Fløgstad employs, which includes other local communities in the history of heavy industry in Sauda, is one that transcends former existing boundaries. However, to be able to envision industrialism in a more comprehensive manner as a global system, it would be desirable to scrutinize the conditions in towns like Nsuta by describing and analysing them in as much detail as conditions in Sauda. It would be extremely interesting to be able to learn about the similarities and differences in these two mutually dependent country towns, in matters that would include the incidence of strikes and labour disputes, the dominating characteristics of the political system,

I 3. See H.W. Andersen, T. Borgersen, T. Brandt, K.O. Eliassen, O.S. Stugu, and A. Øfsti, Fabrikken [The Factory] (Oslo, 2004), pp. 485-5 2.

I4. See K. Fløgstad, Tyrannosaurus text (Oslo, 2003), pp. 9-3 I.

I 5. D. Østerberg, "Kjartan Fløgstads forfatterskap", Syn og Segn, Iо I (1995), pp. 56-67. 
culture, mentalities, gender roles, etc. Wouldn't long-term, holistic studies that included at least two different but connected local communities increase and deepen the awareness of class on the global stage, when studying the circumstances of production and their effects upon the environment?

In spite of this critique, Fløgstad's non-fictional writing can be regarded as a future-oriented model of global, local, and environmental studies in history. Methodologically, it combines the approaches of business and local history with the analytical approach of research on global commodity chains, and extents the frontiers of labour history to a empirical comparison of conditions of production and labour control at the different nodes of a transnational commodity chain. First of all, Fløgstad points the reader's attention to the global capitalistic economic system, of which the heavy industry in Sauda was arguably part. Secondly, he highlights that Sauda was connected to a twin town in Ghana by a commodity chain. And thirdly, and at the same time, he focuses upon the metabolism between human beings and nature at the local nodes of the commodity chain, and this is a concern that continues throughout the book.

In order to prevent misunderstandings: I am not claiming that local, global, and environmental historical perspectives are not found in historical research on transnational labour. My point is that Fløgstad uses the perspectives mentioned above in a particularly thorough and conscientious manner, and that together they constitute the primary perspective that he uses to portray working and living conditions at the nodes of a transnational commodity chain. Thus Fløgstad's work on the working and living conditions at the nodes of a transnational commodity chain are timely because they give vent to the very contemporary awareness of global relationships and how these affect production and the environment. 